\title{
A general dental practitioner's view of the 90th General Session of the International Association of Dental Research
}

IN BRIEF
Reports on the 90th IADR Conference in
Brazil.
Offers tips for first time international
conference goers.
- Supplies background to rapidly advancing
field of dentistry in Brazil.

\author{
M. Austin ${ }^{1}$
}

A review of the 90th General Session of the International Association of Dental Research (IADR), held at Iguaçu Falls, Brazil from 20-23 June 2012, from a delegate's perspective.

Brazil, with a population of 190 million, is one of the most rapidly advancing countries dentally with 191 training programmes for undergraduate dentists ${ }^{1}$ but this 90th Session was the first ever held by the IADR in South America. The meeting was scheduled to take place in Rio de Janeiro but as the date for the UN Conference for Sustainable Development was delayed two weeks because of the Queen's Jubilee celebrations, a new venue had to be found at short notice. This created a logistical challenge for this year's IADR President Dianne Rekow, also Dean of King's College Dental Institute, and her organising committees.

Iguaçu Falls is essentially two towns and two national parks situated either side of the border which runs between Brazil and Argentina through the River Iguaçu. It is the site of the most spectacular collection of waterfalls in the world and located near the Itaipu dam (Fig. 1), the world's largest single hydroelectric system that provides 25\% of Brazil's electricity, saving the equivalent of approximately 500,000 barrels of oil a day.

The session and exhibition was held on the Brazilian side at the two biggest hotels in Iguaçu with convention facilities and also at the main convention centre, for

The Pantiles Quality Dental Care, Shirley Drive, Hove, East Sussex, BN3 60P

Correspondence to: Dr Michael Austin

Email: michaelwarrenaustin@tiscali.co.uk

Accepted 30 July 2012

DOI: 10.1038/sj.bdj.2012.836

${ }^{\circ}$ British Dental Journal 2012; 213: 301-302 the trade exhibition and poster displays, which was near the airport. Among the trade stands at the convention centre were stands from Kings College, UCL, Newcastle and Leeds Universities. A continuous system of free buses for the 4,000 delegates had to be kept running between the three sites and all the other hotels where delegates were staying. Travelling to the new venue in central south Brazil was made more difficult for overseas delegates who needed to fly to Rio or San Paulo first and then take a regional flight to Iguaçu.

However, the positive side of this was that one had an opportunity to spend a few days in Rio and learn about Joaquim Jose da Silva Xavier, Brazil's most famous dentist, colloquially known as Tiradentes, Portuguese for toothpuller. Tiradentes was one of the folk heroes fighting for Brazilian independence from Portugal, who was subsequently imprisoned and then hanged and quartered on 21 April 1792 (Fig. 2). The day is now celebrated as a Brazilian national holiday. There are numerous statues of Joaquim Jose da Silva Xavier and a palace, square and many streets are named after him. There is even a city named Tiradentes in Minas Gerais state and his face appears on a five cent coin.

The scientific meeting consisted of approximately 3,000 papers and posters, with one and a half hour symposia, hands on workshops and poster displays; which were all in English. This reviewer attended a 7 am breakfast welcome for new members sponsored by Colgate and

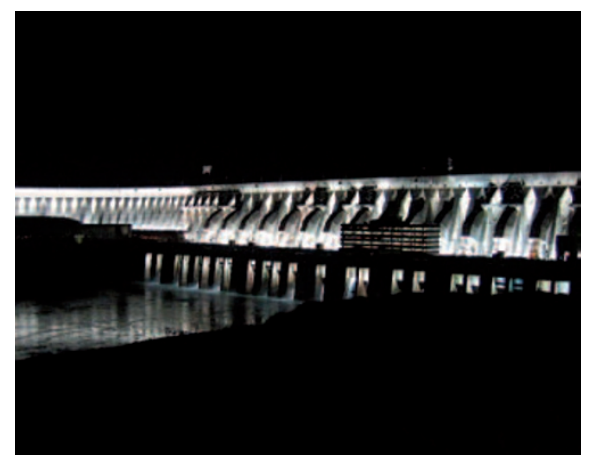

Fig. 1 The Itaipu dam at night, courtesy of henriberguius at http//:flicr.com/ photos/15087,210@NO0/309,644,595

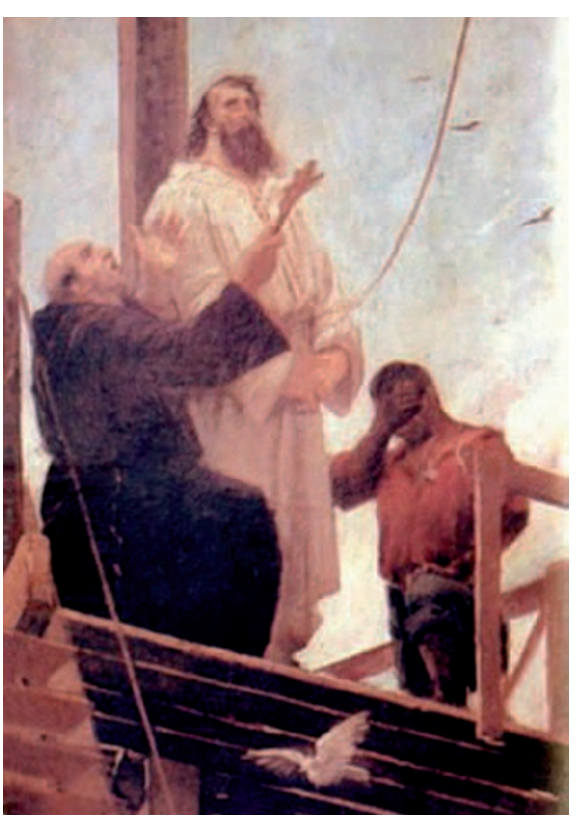

Fig. 2 Aurelio de Figueiredo, Martydom of Tiradentes 1893, Museu Historico National, Rio de Janeiro, Brazil

a symposium on dental fear and anxiety where there were very few delegates in the audience, perhaps because of the 
freezing temperature due to powerful airconditioning. A well-attended and lively symposium was held on mouthrinses, dentifrices and toothbrushes. Several reports from researchers at Johnson \&t Johnson indicated that the addition of essential oils to mouthwashes significantly reduced gingivitis. Of more clinical interest to this reviewer was the keynote address by S. Paris of the University of Kiel, Germany, on caries management by resin infiltration as part of the cariology and erosion symposium. In summary, early proximal carious lesions are treated by separating teeth, etching with 15\% hydrochloric acid and then infiltrating with composite resin which is light cured. Under rubber dam of course! This minimally invasive technique preserves the marginal ridge and has a good success rate. Monitoring is done using sophisticated film holders that exactly replicate film alignment.

Of particular interest to anyone working within a GDS/PDS contract in the UK was a paper given by Rebecca Harris of Liverpool University. Rebecca spoke about using institutional theory to understand practitioner gaming behaviour, which basically was about the manipulation of trust (by both sides) in the relationship, particularly covering grey areas between the contract providers (the PCTs) and the provider of treatment and performers in the NHS Dental Service (the dentists). For those who were disappointed by a poster rejection, there was a useful session on getting your abstracts accepted, given by the IADR President-elect, Mary MacDougal, who will chair next year's meeting in Seattle. On the social side, there was a general, poolside Brazilian night and by invitation only, Korean, Chinese and Japanese nights. There was a dental materials reception and also a King's College reception, where this reviewer had the honour of meeting one of the men who invented the adhesive bridge. ${ }^{2}$

This reviewer's tips for first time overseas conference goers, based on his and colleagues' experiences are:

- Book both flights and accommodation at the same time, as you may get to your destinations but have nowhere other than inferior places to stay

- Travel hand luggage only if at all possible and your bags will not get lost

- Allow plenty of time between connections, as flights are often delayed
- Read a guide book for safety precautions and useful phrases

- Take some local currency with you as local ATMs do not always work with foreign cards

- Inform your bank where you are going

- Take a spare pair of glasses for when they get lost in the breakers of the South Atlantic

- Have some loperamide hydrochloride (Imodium) with you just in case!

In conclusion, the overall impressions gained from this conference were that academics work very hard to meet their colleagues, exchange new ideas and further dental research often with the collaboration and support of the dental industry and pharmaceutical concerns. For generalist practitioners, international meetings increase ones knowledge of world dentistry, broadens your mind, and revitalises one's interest in dentistry.

Well done IADR!

1. Saliba N A, Moimaz S A, Garbin C A, Diniz D G Dentistry in Brazil: its history and current trends. J Dent Educ 2009; 73: 225-231.

2. Livaditis G J, Thompson V P. Etched castings: an improved retentive mechanism for resin-bonded retainers. J Prosthet Dent 1982; 47: 52-58. 